\title{
The Role of Personality Traits in Assessing the State of the Russian Society by Persons with Different Economic Behaviour
}

\author{
Maria Gagarina
}

Ph.D. in Psychology, Associate Professor

Associate Professor of the Department of Personnel Management and Psychology, Financial University Institute of Psychology of the Russian Academy of Science, Researcher at the laboratory of social and economic psychology

MGagarina@fa.ru

\section{Abstract}

The article describes what indicators of the condition of society are used in Russia and abroad. Publications in which happiness, subjective economic well-being, life satisfaction, subjective quality of life and others are considered in this capacity, are reviewed. The question of the role of personality traits in assessing the situation in the country is raised, as well as the impact of these assessments on the economic behaviour of citizens. The results of the empirical study of 260 subjects using questionnaires, which include questions about the political, psychological, social, economic situation in the country, economic behaviour and psycho-diagnostic tests, are presented. The interrelations of assessments of the political and psychological situation in the country with personal traits and debt behaviour are revealed. Extraversion and openness to experience are negatively, and conscientiousness is positively interconnected with positive assessments of the state of the Russian society. The differences in assessments of the state of the Russian society among respondents with different investment preferences are described.

Keywords: political, social and psychological state of society; subjective assessment of the state of society; subjective economic well-being; personality traits; economic behaviour; investment behaviour, debt behaviour, crypto-currency mining

JEL Classification: C91, D14, D84

\section{The Relevance of the Study and Background}

In most international studies, quality of life, well-being and sustainable development are used as indicators of the state of society (Aisyah Abu Bakar et al., 2015; Aisyah Abu Bakar et al., 2016; Handan Turkoglu, 2015; Jakupov et al., 2012; Kelley \& Evans, 2017; Proto \& Rustichini, 2015; Firat \& Boyer, 2015; Roland-Levy, Boumelki \& Guillet, 2010). These concepts can relate differently to each other: to be analyzed independently, one concept to enter into another or to unite and create new terms. In research of Russian scientists, the situation is similar: life satisfaction considered as a psychological equivalent of happiness, or as its components and even as a prerequisite. In gen- eral, happiness, subjective well-being, life satisfaction, subjective quality of life, the meaning of life - being different concepts cover one ontological field and are closely related to one another (Zhuravlyov \& Yurevich, 2014). However, the high level of income does not guarantee life satisfaction (Ilin \& Morev, 2016, p. 927).

The most detailed analysis of indicators of well-being and quality of life is given in Aisyah Abu Bakar et al. (2016): the article summarizes the data of The Malaysia Quality of Life Reports (MQLI) published in 1999, 2002, 2004 and 2011. The validity of the identified approaches to measuring the impact of economic development on the social development of Malaysia through a set of social indicators is evaluated. The Malaysia Quality of Life Reports (MQLI) and the Malaysia 
Wellbeing Reports (MWI) welfare reports claim a holistic, balanced approach that includes a variety of indicators.

The article of Aisyah Abu Bakar et al. (2015), written on the basis of the same reports, but published one year earlier, shows the relationship between well-being and sustainability, which is the basis for the concept of sustainable wellbeing. Handan Turkoglu (2015) also shows the relationship between sustainable development and the quality of life. External, economic, social, physical and health indicators are considered in terms of their contribution to the strategy of sustainable development. The subjective quality of life illustrates the quality of life as a psychological state of life satisfaction, rather than objective conditions (physical, social, economic), although they are interrelated. An attempt to create an index of the macro psychological state of society was also undertaken by Russian scientists (Yurevich et al., 2007). The question "How do Russians assess the situation in their country?" seems relevant, especially in the context of its relationship with economic behaviour.

In this article, we will try to describe how Russians evaluate the socio-psychological and political situation in Russia and how these assessments are related to their personal characteristics and economic behaviour. We focused our attention on the respondents' economic behaviour and investment preferences. This choice is due to the fact that the shift in economic behaviour (from borrowing to saving, for instance) is connected with the way respondents assess their prospects. Uncertainty about future events is associated with individuals with financial risks, and the prospect of not being able to pay off the debts is frightening, up to suicidal attempts. This causes people to develop savings plans and overcome their desire to spend money as soon as they do. The relationship between consumption, savings and debt is as follows: in the case of saving - consumption is delayed, unlike a loan - it can meet the need immediately. Debtors have a shorter time perspective and a number of certain personality traits, according to Nyhus and Webley (2001). Savings behaviour, contrary, implies the ability to connect the present and the future and is the result of the prevalence of the desire for benefit in the long run over the motivation to spend money immediately. Roland-Levy et al. (2010) suggested that a fear about the financial crisis would provoke a desire to save more and borrow less, but the hypothesis was not confirmed and the attitude to the financial crisis affected neither savings nor borrowing behaviour. The difference between saving and investing is that investing is an active process aimed at multiplying existing assets, and saving is only to preserve them. E.R. Bezsmertnaya (2016) explains the Russians low engagement into investment behaviour by a low level of financial literacy and the lack of an investment culture of citizens, as well as a low level of trust in financial institutions. The readiness to invest also reflects people's trust in Russian authorities (Dejneka \& Vartanova, 2012). In addition, the higher socio-psychological and political instability in the country is, the higher the belief in accidental enrichment and gambling.

The psychological state of Russian society, in terms of its social significance, is comparable to its political and economic characteristics. There are different approaches to its measurement as we understood from the beginning of our review. It was even suggested to monitor the psychological state of Russian society in terms of the dynamics of the spread of suicidal mortality, which indicates the degree of adaptation of the population to the existing conditions of life (Ilin \& Morev, 2016, p. 925).

In the works of Hashchenko (2012) "subjective economic well-being" (SEW) is analyzed in details and shown on the Russian sample that the amount of income is gaining psychological value in richer people. The level of SEW is minimally dependent for low income, but it increases significantly when its size reaches or exceeds normal (average) prosperity according to respondents' estimates.

According to statistics for 2017, the main factors of concern for Russians remain fears associated with price increases and international conflicts. Yurevich (2009) notes that the feeling of stability for the majority has been replaced by a sense of despair, oppression, and some social rejection, but the conclusion that "the phenomenon of feeling the stability of one's position is not valid for Russia" is unfounded.

The psychological attitude to economic and political stability depends not only on the objective situation and its interpretation by the subject but also on how this subject relates to the 
state, as well as on its individual psychological characteristics, particular situation and general mood. One of the most important individual psychological characteristics is life satisfaction, which to some extent reflects the assessment of "stability" at the personal level (Dejneka \& Vartanova, 2012, p. 2)

In the article by Proto and Rustichin (2015), personality traits are seen as mediators between income and life satisfaction. The effect of neuroticism, which measures sensitivity to threat and punishment, is strong in both the British Household Panel Survey and the German Socioeconomic Panel. It was found that individuals with a higher Neuroticism score enjoy extra income more than those with a lower score if they are poorer, and enjoy extra income less if they are richer. When the interaction between income and Neuroticism is introduced, income does not have a significant effect on its own. To interpret the results, Proto and Rustichini (2015) presented a simple model based on Prospect Theory, where they assumed that: (i) life satisfaction is dependent on the gap between aspired and realized income, and this is modulated by Neuroticism and (ii) income increases in aspirations with a slope less than unity, so that the gap between aspired and realized income increases with aspirations. From the estimation of this model, Proto and Rustichini argued that poorer individuals tend to overshoot in their aspirations, while the rich tend to under-shoot. The estimation of the model also shows a substantial effect of traits on income. A study conducted by Benjamin et al. (2011) showed that overall satisfaction with the lives of respondents with high Neuroticism decreases more quickly for a high-income level.

Bujor and Turliuc (2014) describe personal, family and emotional predictors of subjective well-being. In their paper, well-being is operationalized through positive affects, negative affects, emotional distress, and life satisfaction. This research integrates three concepts (personality (measured by Big 5 inventory), family correlates and emotion regulation) in a predictive model of well-being.

The results showed that emotional stability predicts well-being on all four dimensions: positive affects, negative affects, emotional distress and life satisfaction. Emotion regulation strategies are predictors for (positive and negative) affects only, and not for emotional distress or life satisfaction

Summing up the theoretical analysis of domestic and foreign literature, we formulated the following hypothesis: there is a connection between the assessments of the political, economic and psychological situation in the country, personal traits and economic behaviour. Following other authors (Bujor \& Turliuc, 2014; Kelley \& Evans, 2017), we used the taxonomy of the Big Five to determine personality traits. As types of economic behaviour, we considered debt behaviour that we have already analyzed in previous papers (Gagarina \& Shantseva, 2017; Smurygina \& Gagarina, 2016) and investment behaviour, by sampling individuals investing in securities (stocks and bonds) and those who invest in crypto-currency and mining equipment. The latter was taken by us since this type of activity is characterized by a high degree of risk, as in scientific articles Eng-Tuck Cheah and John Fry (2015) raise the question of the actual cost of bitcoin (fundamental value) and the signs of a bubble in the crypto-currency market. At the same time, the authors prove that the fundamental cost of bitcoin is zero and its growth is largely determined by speculation.

\section{Methodology}

To study the representations about the situation in Russia, we used a questionnaire, which included the following blocks of questions: 1) Evaluate, which, in your opinion, is the psychological atmosphere in Russia today; 2) Evaluate, which, in your opinion, is the political situation in Russia today.

Each characteristic was presented in the form of two antonymous adjectives and bipolar scales. On each scale there should be only one estimate, where 3 is a strong expression; 1 - poor quality of expression. When processing the results, the bipolar scale was converted to a unipolar scale (from 1 to 7 ).

Then followed the assessment of the social and economic situation in the country and assessment of subjective economic well-being.

We assessed personality traits with A short portrait questionnaire of the Big Five; debt behaviour and debt attitudes with Questionnaire of debt behaviour of M. Gagarina and investment behaviour (and preferences) on the experience 
Table 1

Descriptive statistics and t-test for representations about the political situation in Russia of male and female respondents

\begin{tabular}{lccccccc}
\hline \multirow{2}{*}{ Political situation in Russia } & \multicolumn{2}{c}{ Males, $\mathbf{N}=\mathbf{8 6}$} & \multicolumn{2}{c}{ Females, $\mathbf{N}=130$} & \multirow{2}{*}{$\mathbf{t}$} & p \\
\cline { 2 - 5 } & $\mathbf{M}$ & $\mathbf{S D}$ & $\mathbf{M}$ & $\mathbf{S D}$ & & \\
\hline Explosive/Calm & 3.6 & 1.62 & 3.6 & 1.52 & -0.1 & 0.903 \\
Authoritarian/Democratic & 2.9 & 1.54 & 3.4 & 1.62 & -2.4 & 0.016 \\
Contradictory/Consistent & 3.1 & 1.57 & 3.6 & 1.71 & -1.9 & 0.057 \\
Irritating/Restful & 2.9 & 1.42 & 3.4 & 1.48 & -2.0 & 0.044 \\
Hostile/Friendly & 3.2 & 1.39 & 3.7 & 1.43 & -2.9 & 0.004 \\
Tense/Relaxed & 3.0 & 1.38 & 3.2 & 1.62 & -1.0 & 0.343 \\
Unstable/Stable & 4.2 & 1.98 & 4.0 & 1.82 & 0.5 & 0.652 \\
Unpredictable/Predictable & 4.5 & 1.97 & 4.2 & 1.83 & 1.3 & 0.207 \\
Dependent/Independent & 3.1 & 1.56 & 3.6 & 1.57 & -1.6 & 0.116 \\
Economic situation in Russia & 2.4 & 0.97 & 2.6 & 0.89 & -1.8 & 0.075 \\
Social situation in Russia & 2.6 & 0.82 & 2.7 & 0.81 & -0.5 & 0.610 \\
\hline
\end{tabular}

Source: author's calculations.

of investing in various products of the financial market.

We interviewed 216 people, including 86 males and 130 females.

\section{Results and Discussion}

First, we will consider the gender differences in the assessments of the political, psychological and social situation in Russia. The results are presented in Tables 1 and 2.

The political situation in Russia, according to males, is more authoritative, hostile and irritating than to females. Differences in the assessment of the economic situation (living standards, prospects of development, etc.), as well as the social situation (conflicts and contradictions between people, social strata, etc.) and subjective wellbeing, have not been revealed.

Analyzing the psychological atmosphere in Russia (Table 2), males have significantly more negative assessments than females, considering it more unfree, tense, aggressive and hopeless.

Our sample included respondents from Moscow, the Moscow Region, Saratov, Samara and Cheboksary. However, due to the small representation of the remaining regions, we compared the views of only residents of Moscow and the Moscow Region. There were no significant differences in any of the parameters.
Further, we were interested in how the assessments of the situation in Russia are connected with personality traits and economic behaviour. For this, we calculated the Pearson correlation coefficients and carried out a comparative analysis.

First, we will analyse how the representations of the situation in Russia are related to personality traits (Table 3).

The assessments of the political situation in Russia turned out to be related to personality traits in the following way. Extroversion is inversely related to the assessment of the political situation as consistent $(\mathrm{r}=-0.2 ; \mathrm{p}<0.05)$. That is, the more a person is active, sociable and aimed at interacting with other people, the more he considers the political situation in the country to be contradictory. The openness to experience is inversely related to the assessment of the political situation as calm $(\mathrm{r}=-0.2, \mathrm{p}<0.05)$. That is, the more a person is inquisitive, open to innovations and creative, the more he is inclined to assess the political situation as unsettled. Consciousness is positively interconnected with the assessment of the political situation as friendly $(r=0.2, p<0.05)$ and the social situation as calm $(r=0.2, p<0.05)$ : the more a person expresses responsibility, the propensity to planning and following the rules, the more highly 
Table 2

Descriptive statistics and t-test for representations about the psychological atmosphere in Russia of male and female respondents

\begin{tabular}{|c|c|c|c|c|c|c|}
\hline \multirow{2}{*}{$\begin{array}{l}\text { The psychological atmosphere in } \\
\text { Russia }\end{array}$} & \multicolumn{2}{|c|}{ Males, $\mathbf{N}=86$} & \multicolumn{2}{|c|}{ Females, $\mathbf{N}=130$} & \multirow{2}{*}{$\mathbf{t}$} & \multirow{2}{*}{$\mathbf{p}$} \\
\hline & $M$ & SD & $M$ & SD & & \\
\hline Not Free/Free & 3.2 & 1.55 & 3.7 & 1.57 & -2.5 & 0.012 \\
\hline Tense/Relaxed & 2.6 & 1.26 & 3.0 & 1.26 & -2.1 & 0.036 \\
\hline Aggressive/Benevolent & 3.2 & 1.33 & 3.7 & 1.25 & -2.5 & 0.014 \\
\hline Sad/Joyful & 3.1 & 1.44 & 3.5 & 1.43 & -1.8 & 0.071 \\
\hline Hopeless/Promising & 3.6 & 1.44 & 4.2 & 1.44 & -2.9 & 0.005 \\
\hline Hostile/Friendly & 3.6 & 1.35 & 4.0 & 1.36 & -1.9 & 0.057 \\
\hline Fussy/Peaceful & 3.3 & 1.33 & 3.2 & 1.54 & 0.2 & 0.857 \\
\hline Dull/Cheerful & 3.5 & 1.66 & 3.7 & 1.52 & -0.8 & 0.424 \\
\hline Frustrating/Calming & 3.4 & 1.39 & 3.5 & 1.31 & -0.4 & 0.665 \\
\hline
\end{tabular}

Source: author's calculations.

Table 3

Pearson's correlation coefficients for assessments of the political, social and economic situation in Russia and the personality traits of the respondents

\begin{tabular}{|c|c|c|c|c|c|}
\hline $\begin{array}{c}\text { Political situation in } \\
\text { Russia }\end{array}$ & Extraversion & $\begin{array}{l}\text { Neuroti- } \\
\text { cism }\end{array}$ & $\begin{array}{l}\text { Openness to expe- } \\
\text { rience }\end{array}$ & $\begin{array}{l}\text { Conscientious- } \\
\text { ness }\end{array}$ & $\begin{array}{l}\text { Agreeable- } \\
\text { ness }\end{array}$ \\
\hline Explosive/Calm & -0.1 & -0.1 & $-0.2^{*}$ & -0.1 & 0.1 \\
\hline $\begin{array}{l}\text { Authoritarian/ } \\
\text { Democratic }\end{array}$ & 0.0 & 0.1 & 0.0 & 0.0 & 0.1 \\
\hline $\begin{array}{l}\text { Contradictory/ } \\
\text { Consistent }\end{array}$ & $-0.2^{*}$ & 0.0 & 0.0 & 0.0 & 0.1 \\
\hline Irritating/Restful & 0.0 & -0.1 & -0.2 & 0.0 & 0.2 \\
\hline Hostile/Friendly & 0.0 & 0.0 & 0.0 & $0.2^{*}$ & 0.2 \\
\hline Tense/Relaxed & 0.1 & 0.0 & 0.0 & 0.1 & 0.1 \\
\hline Unstable/Stable & -0.2 & 0.1 & -0.1 & -0.1 & 0.0 \\
\hline $\begin{array}{l}\text { Unpredictable/ } \\
\text { Predictable }\end{array}$ & 0.0 & 0.0 & 0.0 & -0.1 & 0.0 \\
\hline $\begin{array}{l}\text { Dependent/ } \\
\text { Independent }\end{array}$ & 0.1 & -0.1 & 0.1 & 0.1 & 0.1 \\
\hline $\begin{array}{l}\text { Economic situation in } \\
\text { Russia }\end{array}$ & 0.0 & 0.1 & 0.1 & 0.0 & 0.1 \\
\hline $\begin{array}{l}\text { Social situation in } \\
\text { Russia }\end{array}$ & 0.0 & 0.0 & 0.1 & $0.2^{*}$ & 0.0 \\
\hline
\end{tabular}

* Significant at $\mathrm{p}<0.05$.

Source: author's calculations.

he assesses the political situation as a friendly and social situation as calm. For neuroticism and agreeableness, significant interrelations have not been found.

The following significant correlations of assessments of the psychological situation in the country with personality traits were obtained.
Openness to experience is inversely related to the assessment of the situation as peaceful $(r=-0.2 ; p<0.05)$. The consciousness is positively correlated with the assessments of the psychological situation as benevolent $(r=0.2$; $p<0.05)$, promising $(r=0.2, p<0.05)$ and cheerful $(r=0.2, p<0.05)$. 
Table 4

Pearson's correlation coefficients for assessments of the psychological situation in the country and the personality traits of the respondents

\begin{tabular}{lccccc}
\hline $\begin{array}{c}\text { The psychological at- } \\
\text { mosphere in Russia }\end{array}$ & Extraversion & $\begin{array}{c}\text { Neuroti- } \\
\text { cism }\end{array}$ & $\begin{array}{c}\text { Openness to expe- } \\
\text { rience }\end{array}$ & $\begin{array}{c}\text { Conscientious- } \\
\text { ness }\end{array}$ & $\begin{array}{c}\text { Agreeable- } \\
\text { ness }\end{array}$ \\
\hline Not Free/Free & -0.1 & 0.0 & -0.1 & 0.0 & 0.1 \\
Tense/Relaxed & 0.0 & 0.0 & -0.1 & 0.0 & 0.1 \\
Aggressive/Benevolent & 0.0 & 0.0 & 0.0 & $0.2^{*}$ & 0.0 \\
Sad/Joyful & 0.1 & -0.1 & 0.1 & 0.1 & 0.1 \\
Hopeless/Promising & 0.1 & -0.1 & 0.0 & $0.2^{*}$ & $0.2^{*}$ \\
Hostile/Friendly & 0.1 & -0.1 & 0.1 & 0.2 & 0.1 \\
Fussy/Peaceful & 0.0 & -0.1 & $-0.2^{*}$ & 0.0 & 0.0 \\
Dull/Cheerful & 0.1 & -0.1 & 0.0 & $0.3^{*}$ & 0.1 \\
Frustrating/Calming & -0.1 & 0.0 & 0.0 & 0.1 & 0.1 \\
\hline
\end{tabular}

* Significant at $p<0.05$.

Source: author's calculations.

Table 5

Pearson's correlation coefficients for assessments of the political, social and economic situation in Russia and Debt behaviour questionnaire scales, age and subjective well-being (SWB)

\begin{tabular}{lcccccc}
\hline $\begin{array}{c}\text { The political situation in } \\
\text { Russia }\end{array}$ & $\begin{array}{c}\text { Debt } \\
\text { avoidance }\end{array}$ & $\begin{array}{c}\text { Rational debt } \\
\text { behaviour }\end{array}$ & $\begin{array}{c}\text { Debt } \\
\text { attitudes }\end{array}$ & $\begin{array}{c}\text { Internality } \\
\text { in debt }\end{array}$ & Age & SWB \\
\hline Explosive/Calm & 0.0 & -0.1 & 0.0 & -0.1 & 0.2 & 0.0 \\
Authoritarian/Democratic & -0.1 & -0.1 & 0.1 & -0.1 & 0.1 & 0.0 \\
Contradictory/Consistent & 0.0 & 0.0 & 0.1 & -0.1 & 0.2 & 0.0 \\
Irritating/Restful & 0.0 & 0.0 & 0.1 & 0.0 & 0.0 & 0.0 \\
Hostile/Friendly & -0.1 & -0.1 & 0.1 & -0.1 & $0.2^{*}$ & 0.0 \\
Tense/Relaxed & -0.1 & 0.0 & 0.0 & -0.1 & 0.2 & $0.2^{*}$ \\
Unstable/Stable & 0.0 & 0.0 & 0.0 & 0.0 & $0.2^{*}$ & 0.0 \\
Unpredictable/Predictable & 0.0 & 0.0 & -0.1 & -0.1 & 0.1 & -0.1 \\
Dependent/Independent & 0.0 & 0.0 & 0.0 & 0.0 & 0.1 & 0.0 \\
Economic situation in & 0.0 & 0.0 & 0.2 & 0.0 & 0.1 & 0.1 \\
Russia & & 0.1 & & & & \\
Social situation in Russia & 0.0 & 0.0 & 0.0 & 0.1 & $-0.2^{*}$ \\
\hline
\end{tabular}

* Significant at $p<0.05$.

Source: author's calculations.

Next, we looked at how assessments of the political (Table 5) and psychological (Table 6) situation in the country are related to age, subjective economic well-being and debt behaviour.

The more highly respondents assess their subjective economic well-being, the more they perceive the political situation as relaxed and less positively assess the social situation. Age is positively correlated with the assessment of the political situation as friendly and stable.

Assessments of the political situation in Russia are not related to any scales of debt behaviour questionnaire scales. 
Table 6

Pearson's correlation coefficients for assessments of the psychological situation in Russia and Debt behaviour questionnaire scales, age and subjective well-being (SWB)

\begin{tabular}{lcccccc}
\hline $\begin{array}{c}\text { The psychological atmosphere in } \\
\text { Russia }\end{array}$ & $\begin{array}{c}\text { Debt } \\
\text { avoidance }\end{array}$ & $\begin{array}{c}\text { Rational debt } \\
\text { behaviour }\end{array}$ & $\begin{array}{c}\text { Debt } \\
\text { attitudes }\end{array}$ & $\begin{array}{c}\text { Internality } \\
\text { in debt }\end{array}$ & Age & SWB \\
\hline Not Free/Free & 0.2 & 0.2 & $0.3^{*}$ & 0.2 & 0.1 & 0.1 \\
Tense/Relaxed & 0.1 & 0.1 & 0.2 & 0.1 & 0.0 & 0.1 \\
Aggressive/Benevolent & 0.1 & 0.1 & $0.2^{*}$ & 0.1 & 0.1 & 0.0 \\
Sad/Joyful & 0.0 & 0.1 & 0.1 & 0.0 & 0.1 & 0.0 \\
Hopeless/Promising & 0.0 & 0.0 & 0.1 & 0.0 & 0.2 & -0.1 \\
Hostile/Friendly & -0.1 & -0.1 & 0.0 & -0.1 & 0.2 & -0.1 \\
Fussy/Peaceful & $-0.3^{*}$ & $-0.2^{*}$ & -0.1 & $-0.2^{*}$ & $0.3^{*}$ & 0.0 \\
Dull/Cheerful & -0.1 & 0.0 & 0.0 & -0.1 & 0.1 & 0.1 \\
Frustrating/Calming & 0.0 & 0.0 & 0.1 & 0.0 & $0.2^{*}$ & 0.0 \\
\hline
\end{tabular}

* Significant at $p<0.05$.

Source: author's calculations.

Table 7

Descriptive statistics and t-test for representations about the situation in Russia of respondents trading and not trading securities

\begin{tabular}{lccccccccc}
\hline & \multicolumn{3}{c}{ Do not trade securities } & \multicolumn{3}{c}{ Trade securities } & \multirow{2}{*}{ t } & p \\
\cline { 2 - 7 } & M & SD & N & M & SD & N & & \\
\hline Hostile/Friendly & 3.3 & 1.36 & 24 & 4.0 & 1.35 & 183 & -2.45 & 0.015 \\
Unstable/Stable & 3.1 & 1.47 & 24 & 4.2 & 1.89 & 184 & -2.75 & 0.006 \\
\hline
\end{tabular}

Source: author's calculations.

Table 8

Descriptive statistics and t-test for representations about the situation in Russia of respondents investing and not investing in financial pyramids

\begin{tabular}{lcccccccc}
\hline & \multicolumn{3}{c}{$\begin{array}{c}\text { Do not ready to invest in financial } \\
\text { pyramids }\end{array}$} & \multicolumn{2}{c}{$\begin{array}{c}\text { Ready to invest in financial } \\
\text { pyramids }\end{array}$} & t & p \\
\cline { 2 - 7 } & $\mathbf{M}$ & SD & N & M & D & N & & \\
\hline Fussy/Peaceful & 3.2 & 1.49 & 165 & 4.5 & 0.84 & 16 & -2.09 & 0.038 \\
Dull/Cheerful & 3.5 & 1.66 & 99 & 5.2 & 1.10 & 15 & -2.26 & 0.026 \\
Tense/Relaxed & 3.0 & 1.55 & 165 & 4.3 & 1.86 & 16 & -2.01 & 0.046 \\
\hline
\end{tabular}

Source: author's calculations.

Assessments of the psychological situation in the country are not related to assessments of subjective psychological well-being but are related to age. The older the respondents, the more they evaluate the psychological situation as friendly $(r=0.2, p<0.05)$, peaceful $(r=0.3$; $\mathrm{p}<0.05)$ and calming $(\mathrm{r}=0.2 ; \mathrm{p}<0.05)$.

Evaluation of the psychological situation in Russia as peaceful is negatively associated with debt avoidance $(r=-0.3 ; p<0.05)$, rational debt behaviour $(r=-0.2 ; p<0.05)$, negative debt at titudes $(r=-0.2, p<0.05)$. That is, the more respondents tend to consider the psychological situation in Russia as fussy, the more they are convinced that they are responsible for their debts alone, avoid borrowing, and if they borrow, they calculate how and when they will pay it back in full. A representation that living with 
Table 9

Descriptive statistics and t-test for representations about the situation in Russia of respondents investing and not investing in financial pyramids

\begin{tabular}{|c|c|c|c|c|c|c|c|c|}
\hline & \multicolumn{3}{|c|}{$\begin{array}{l}\text { Do not participate in the } \\
\text { crypto-currency market }\end{array}$} & \multicolumn{3}{|c|}{$\begin{array}{l}\text { Participate in the crypto- } \\
\text { currency market }\end{array}$} & \multirow{2}{*}{$\mathbf{t}$} & \multirow{2}{*}{$\mathbf{p}$} \\
\hline & M & SD & $\mathbf{N}$ & M & SD & $\mathbf{N}$ & & \\
\hline Not Free/Free & 3.2 & 1.57 & 124 & 5.2 & 1.33 & 11 & -4.15 & 0.000 \\
\hline Tense/Relaxed & 2.7 & 1.27 & 124 & 3.5 & 1.13 & 11 & -2.20 & 0.030 \\
\hline Aggressive/Benevolent & 3.3 & 1.32 & 123 & 4.2 & 1.33 & 11 & -2.08 & 0.039 \\
\hline Irritating/Restful & 3.3 & 1.31 & 124 & 4.3 & 1.19 & 11 & -2.29 & 0.024 \\
\hline Authoritarian/Democratic & 2.9 & 1.56 & 124 & 4.0 & 1.10 & 11 & -2.27 & 0.025 \\
\hline Frustrating/Calming & 3.1 & 1.47 & 124 & 4.3 & 1.56 & 11 & -2.56 & 0.012 \\
\hline Tense/Relaxed & 2.9 & 1.47 & 124 & 4.0 & 1.79 & 11 & -2.31 & 0.022 \\
\hline $\begin{array}{l}\text { Economic situation in } \\
\text { Russia }\end{array}$ & 2.5 & 0.96 & 124 & 3.1 & 1.14 & 11 & -2.04 & 0.044 \\
\hline
\end{tabular}

Source: author's calculations.

debts is not normal is positively associated with the assessment of the psychological situation as benevolent and free.

Then we turned to the economic behaviour of the respondents. We compared the assessments of the situation in Russia of respondents with different investment preferences ( $t$-test): those who invest in securities on the exchange (Table 7 , here and below only significant results are presented), ready to invest in financial pyramids (Table 8) and participate on crypto-currency market (Table 9).

Respondents trading securities on the exchange, rate the political situation in Russia as more hostile and the psychological situation as more unstable than respondents who do not trade. There were no differences in the assessments of the economic and social situation.

Respondents who are ready to invest money in financial pyramids assess the psychological situation as peaceful and cheerful compared to those who are not ready to invest. Differences in the assessment of the political situation are detected by the degree of its tension - those participating in the financial pyramids estimate it as less tense; differences in assessing the social and economic situation are not revealed.

Respondents engaged in the crypto-currency market (by mining crypto-currencies, buying crypto-currency and equipment for mining) are more likely to assess the political situation as free, relaxed, benevolent and calming, and the political situation as democratic, restful, relaxed. They see the economic situation as prosperous. In general, we can say that they are more optimistic, easy-going in their attitudes toward the situation in Russia. In our work (Gagarina \& Lopanova, 2018), performed on a sample of 360 people, we found rather contradicting results about their personal traits. We compared the personal profiles of the above-described investors and got that those who are engaged in mining differ from those who invest in traditional financial instruments and from those who invest in financial pyramids by a lower level of extraversion, openness to experience and agreeableness and higher neuroticism. While investors in financial pyramids and investors in traditional financial instruments differ only in terms of the level of consciousness, which is lower in the latter. So we can assume that such a superficial and demonstratively positive assessment of the social, psychological, political and economic situation in Russia by respondents engaged in the crypto-currency market is a manifestation of psychological defence.

\section{Conclusions}

Summarizing, we can draw the following conclusions. In our sample, males assess the political and psychological situation in Russia more negatively than females. Personality 
traits are also important in shaping the representations of the situation in Russia. The higher the extraversion, the more inconsistent the political situation is assessed. With increasing in openness to experience, the political situation is assessed more restless and fussy. The growth of consciousness is connected with an estimation of a political situation as more friendly, and psychological as more benevolent, promising and cheerful. Debt behaviour is associated only with the assessment of the psychological situation in Russia and is not related to the assessment of political. Investors in financial instruments traded on the exchange have more negative views about the political situation in Russia. Investors in financial pyramids have more positive assessments of the psychological situation in the country. Respondents involved in the crypto-currency market have more positive assessments of the political, psychological and economic situation in the country.

\section{Acknowledgements}

The work was carried out with the financial support of the Russian Foundation for Basic Research (RFBR), grant 17-29-02104 "Indicators and predictors of the psychological condition of the Russian society".

\section{References}

Aisyah Abu Bakar et al. (2015) Modelling Economic Wellbeing and Social Wellbeing for Sustainability: A Theoretical Concept. Procedia Environmental Sciences, 28, 286-296.

Aisyah Abu Bakar et al. (2016) Investigating Rationales of Malaysia Quality of Life and Wellbeing Components and Indicators. Procedia - Social and Behavioural Sciences, 222, 132-142.

Balackij, E. V., \& Ekimova, N. A. (2008). Economic determinants of the psychological development of the society [Ekonomicheskie determinanty psihologicheskogo sostoyaniya obshchestva]. Monitoring obshchestvennogo mneniya: ehkonomicheskie i social'nye peremeny, 2(86), 18-25.

Benjamin, D. J., Heffetz, O., Kimball, M. S., \& Rees-Jones, A. (2012). What do you think would make you happier? What do you think you would choose? American Economic Review, 102(5), 2083-2110. doi:10.1257/ aer.102.5.2083

Bezsmertnaya, E. R. (2016). Private investments into financial market tools: the current state and prospects of development [Investicii naseleniya $\mathrm{v}$ instrumenty finansovogo rynka: tekushchee sostoyanie i perspektivy razvitiya]. Ekonomika. Nalogi. Pravo, 6, 17-25.

Bujor, L., \& Turliuc, M. N. (2014). Personality, Family Correlates and Emotion Regulation as Wellbeing Predictors. Procedia - Social and Behavioural Sciences, 159, 142-146.

Dejneka, O. S., \& Vartanova I.A. (2012). Life satisfaction as a predictor of attitude to economic and political stability of students [Udovletvorennost' zhizn'yu kak prediktor otnosheniya k ehkonomicheskoj i politicheskoj stabil'nosti studencheskoj molodezhi]. Sovremennye problemy nauki i obrazovaniya, 6, 705.

Firat, R. B., \& Boyer, P. (2015). Coalitional affiliation as a missing link between ethnic polarization and well-being: An empirical test from the European Social Survey. Social Science Research, 53, 148-161.

Fry, J., \& Cheah, E-T. (2015). Speculative bubbles in Bitcoin markets? An empirical investigation into the fundamental value of Bitcoin. Economics Letters, 130, pp. 32-36.

Gagarina, M. A., \& Lopanova, N. K. (2018). Tolerance to the uncertainty of people with different strategies of investment behaviour [Tolerantnost $\mathrm{k}$ neopredelennosti u lic s razlichnymi strategiyami investicionnogo povedeniya]. Available at: https://mir-nauki.com/PDF/04PSMN 318.pdf.

Gagarina, M. A., \& Shantseva, A. A. (2017). Socio-psychological peculiarities and level of financial literacy of Russian debtors. Review of Business and Economics Studies, 2, 5-22.

Handan Turkoglu, (2015). Sustainable Development and Quality of Urban Life. Procedia - Social and Behavioural Sciences, 202, 10-14.

Hashchenko, V. A. (2012). Relationship between income and subjective economic well-being: absolute or relative? [Vzaimosvyaz mezhdu dohodom i subektivnym ekonomicheskim blagopoluchiem: absolyutnaya ili otnositelnaya?]. Vestnik Rossijskogo universiteta druzhby narodov. Seriya: Psihologiya i pedagogika, 3, 52-59.

Ilin, V.A., \& Morev, M.V. (2016). Psychological state of the Russian society [Psihologicheskoe sostoyanie rossijskogo obshchestva]. Vestnik RAN, 86(10), 921-932. 
Jakupov, S. M. et al. (2012). Cultural Values as an Indicator of Inter-Ethnic Harmony in Multicultural Societies. Procedia - Social and Behavioural Sciences, 69, 114-123.

Kelleya, J., \& Evans, M. D. R. (2017). Societal Inequality and individual subjective well-being: Results from 68 societies and over 200,000 individuals, 1981-2008. Social Science Research, 62, 1-23.

Nyhus, E.K., \& Webley, P. (2001). The Role of Personality in Household Saving and Borrowing Behaviour. European Journal of Personality, 15, 85-103.

Proto, E., \& Rustichini, A. (2015). Life satisfaction, income and personality. Journal of Economic Psychology, 48, 17-32.

Ridgewell, C., Blackford, J. U., McHugo, M., \& Heckers, S. (2017). Personality traits predicting the quality of life and overall functioning in schizophrenia. Schizophrenia Research, 182, 19-23. doi: 10.1016/j.schres.2016.10.007.

Roland-Levy, C., Boumelki, F-E. P, \& Guillet, E. (2010). Representation of the financial crisis: Effect on social representations of savings and credit. The Journal of Socio-Economics, 39, 142-149.

Smurygina, A., \& Gagarina, M. (2016). Bounded rationality: a psychological analysis of debt behaviour. Review of Business and Economics Studies, 1, 75-84.

Yurevich, A. V., Ushakov, D. V., \& Capenko, I. P. (2007). Quantitative estimation of macro-psychological condition of modern Russian society [Kolichestvennaya ocenka makropsihologicheskogo sostoyaniya sovremennogo rossijskogo obshchestva]. Psihologicheskij zhurnal, 28(4), 23-34.

Yurevich, A. V. (2009). Dynamics of the psychological condition of contemporary Russian society [Dinamika psihologicheskogo sostoyaniya sovremennogo rossijskogo obshchestva]. Vestnik RAN, 79(2), 112-118.

Zhuravlyov, A. L., \& Yurevich, A. V. (2014). Happiness as a scientific category [Schaste kak nauchnaya kategoriya]. Vestnik RAN, 84(8), 715.

Роль личностных черт в оценке состояния российского общества лицами с различным экономическим поведением

Мария Гагарина

Кандидат психологических наук, доцент, доцент кафедры «Управление персоналом и психология», Финансовый университет;

Институт психологии РАН, ассоциированный научный сотрудник лаборатории социальной

и экономической психологии, Москва, Россия

MGagarina@fa.ru

Аннотация. В статье анализируются результаты исследования состояния общества в России по следующим показателям: счастье, субъективное экономическое благополучие, удовлетворенность жизнью, субъективное качество жизни и др. Поднимается вопрос о роли личностных черт в оценке ситуации в стране и влияния этой оценки на экономическое поведение граждан. Приведены результаты анкетирования 260 граждан, в которое были включены вопросы о политической, психологической, социальной, экономической ситуации в стране, экономическом поведении, а также психодиагностические тесты. Выявлена взаимосвязь оценок политической и психологической ситуации в стране с личностными чертами и долговым поведением. Экстраверсия и открытость новому опыту взаимосвязаны отрицательно с позитивными оценками состояния российского общества, а сознательность - положительно. Описаны различия в оценках состояния российского общества между респондентами с разными инвестиционными предпочтениями.

Ключевые слова: политическое, социальное и психологическое состояние общества; субъективная оценка состояния общества; субъективное экономическое благополучие; личностные черты; экономическое поведение; инвестиционное поведение; долговое поведение; майнинг криптовалют 